\title{
Maldições, Fetiches e Comunismo na Crítica da Economia Política: a teoria da alienação de Karl Marx
}

\section{Malediction, Fetish and Communism in the Criticism of Political Economy: the Karl Marx Theory of Alienation}

\section{Artigo \\ Original}

\section{Original}

Paper

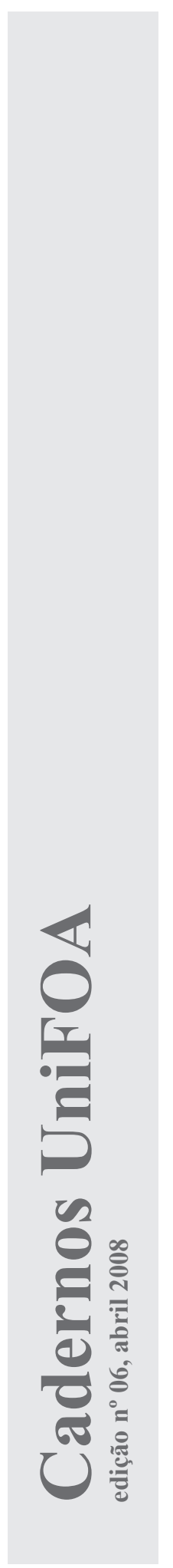

\author{
Rodrigo Castelo Branco ${ }^{1}$
}

Palavras-chaves:

Alienação

Capitalismo

Comunismo

Karl Marx

\begin{abstract}
In the economical plan, the alienation and the power of capital over the working class have grown in size with the disassembly of Well-Being social state and the end of real Socialism. The dollar, with the extinction of BrettonWoods monetary-financial agreements, has lost its link with any standard good and it has become the international money for excellence, expanding the USA imperialist power to levels not experimentalized by any dominant great nation. The fetishism of good, which matches its maximum expression in money, has reached a level in which the capital seems to reproduce by itself - money that genders money - getting own life and subordinating the workers interests to the capitalist class interests. These are some of the contemporary questions which the Marxist thinkers face. Is it possible that the "alienation", "fetishism of good" and "reification" categories are capable of help United States in comprehending the actual phase in Capitalism, when the capital in interest seems to dominate everyone? The present study does not intend to answer such a complex question: its aim is only to establish a theorical panorama of the alienation question and the fetishism of good in the Karl Marx theorical work.
\end{abstract}

Key words:

Alienation

Capitalism

Communism

Karl Marx

\section{Introdução}

$\mathrm{Na}$ Era Moderna, a temática da alienação foi um dos focos centrais das artes e das ciências humanas. Livros, músicas, filmes e pinturas retrataram, com argúcia e sensibilidade apuradas, as angústias e sofrimentos dos indivíduos e coletividades na 
sociedade industrial; sociologia, economia e filosofia analisaram as tensões e contradições derivadas do capitalismo e suas conseqüências alienantes sobre classes e povos de todo o planeta.

Muitas das contribuições para a análise da alienação limitaram-se ao exame dos seus sintomas e manifestações aparentes, e poucos foram até a raiz e a essência do problema, ficando restritas a certas dimensões e particularidades da alienação. Segundo versões psicologistas (ex.: existencialismo), a alienação é uma condição inata da existência humana, uma espécie de maldição que nós, seres humanos, vamos carregar como um fardo até o resto de nossas vidas, condenadas ao sofrimento eterno (SCHAFF, 1965).

$\mathrm{Na}$ segunda metade da década de 1950, a problemática da alienação veio à tona dentro do marxismo com o interesse de pesquisadores na retomada da leitura dos textos clássicos e originais de Karl Marx, publicados a partir da década de $1930^{1}$. O tema da alienação sempre foi um tabu dentro do pensamento socialista revolucionário: por diversos motivos ${ }^{2}$, ele ficou restrito a um núcleo muito reduzido de estudiosos e militantes, que logo foram taxados de heréticos pela patrulha ideológica dos órgãos oficiais do "marxismoleninista".

O marxismo desenvolveu a problemática da alienação sob um ponto de vista histórico, analisando o seu nascimento e desenvolvimento nas sociedades organizadas em torno das classes e o seu possível desaparecimento em uma sociedade socialista. A alienação deixa de ser um problema do indivíduo isolado na sociedade para se tornar um produto histórico criado sob certas formas de organização social de produção e reprodução da vida humana, e por isto mesmo, suscetível de mudança de acordo com as interações sociais, ao contrário da "maldição eterna" proposta pelos existencialistas.

Ao responder às questões dos pensadores existencialistas, o marxismo colocou o debate da alienação em novos patamares, evoluindo para novas temáticas e frentes de investigação. Uma das principais fontes de renovação do debate foi aberta pelo texto Reificação, de Georg Lukács, presente no livro História e Consciência de Classe. Segundo o filósofo húngaro, a alienação, nos marcos da sociedade capitalista, transborda da esfera da produção e abarca outros níveis sociais e da própria economia, como o consumo. Posteriormente, outros autores (a chamada Escola de Frankfurt, Lucien Goldmann, István Mészáros) vão seguir essa trilha aberta por Lukács e estudar os efeitos e conseqüências da alienação nas artes, comunicação e ideologia e seus rebatimentos no ser humano.

No plano econômico, a alienação e o poder do capital sobre a classe trabalhadora cresceram de tamanho com o desmonte do Estado do Bem-Estar Social e o fim do socialismo real na ex-União Soviética e no Leste Europeu. O dólar, com a extinção dos acordos monetário-financeiros de Bretton Woods, perdeu seu lastro com qualquer mercadoria-padrão e tornou-se a moeda internacional por excelência, expandindo o poder imperalista estadunidense a níveis nunca antes experimentado por qualquer potência hegemônica.

O fetichismo da mercadoria, que encontra sua expressão máxima no dinheiro, atingiu um patamar no qual o capital parece se reproduzir por si só - dinheiro que gera dinheiro (D-D') - ganhando vida própria e subordinando os interesses dos trabalhadores aos interesses capitalistas de tal forma que os efeitos da dominação da classe proprietária têm sido sentidos nos últimos trinta anos, período de regressão da humanidade à barbárie.

Estas são algumas das questões fundamentais com as quais os pensadores marxistas se defrontam nos dias de hoje. Será que as categorias 'alienação', 'fetichismo da mercadoria' e 'reificação' são capazes de nos auxiliar no entendimento da atual fase do capitalismo, quando o capital a juros parece dominar a tudo e todos? O presente trabalho não pretende responder a tal questão complexa: o seu objetivo é tão somente traçar um panorama teórico da problemática da alienação e do fetichismo da mercadoria na obra teórica de Karl Marx.

\section{A pluridimensionalidade da categoria 'alienação' e a centralidade da sua determinação econômica}

O conceito de alienação é uma temática cara à filosofia clássica alemã. Este conceito não apareceu originariamente nos escritos marxianos sob a marca do trabalho e 
debate filosófico alemão de alienação política e religiosa do ser humano.

A alienação é um processo social que ultrapassa as fronteiras do mundo do trabalho, e chega a abarcar diversos elementos da vida humana. Ela não diz respeito apenas ao trabalhador no processo de trabalho, embora esta seja uma esfera fundamental da alienação, mas ao homem enquanto ser universal genérico, atingindo múltiplas esferas do seu comportamento.

O conceito de alienação é, desde o seu aparecimento, um conceito pluridimensional. Se procurarmos uma definição comum a todas suas dimensões, podemos dizer que objetos materiais ou ideológicos criados por um sujeito, ao se exteriorizarem, dominam e subjugam o seu criador, ganhando vida própria como um ser animado, transformando o sujeito em objeto; coisas e homens trocam de papel e função: enquanto aquele domina, este é dominado. No caso da alienação política, estamos falando do homem e do Estado; na religião, do homem e de Deus; na economia, do homem e do Dinheiro e, posteriormente, do Capital.

Marx não ignora a pluridimensionalidade do conceito, discutindo-a nas críticas a Hegel e Feuerbach durante as primeiras fases da sua evolução teórica. Ele vai, todavia, buscar a raiz do problema da alienação no processo histórico de formação e desenvolvimento das sociedades de classe, na divisão social do trabalho e no aparecimento da propriedade privada, desde o modo de produção escravista até o capitalista. Podemos dizer, resumidamente, que o fenômeno da alienação é, para Marx, um fenômeno histórico que compreende diversas esferas do ser social (política, religião, ideologia), mas encontra sua centralidade na base econômica.

O revolucionário alemão ultrapassa e supera todo o debate teológico e filosófico sobre alienação quando descobre a alienação do trabalho como uma prática social e a elege como denominador comum à multiplicidade de visões a qual o tema alienação está submetido. Indo mais além, Marx chega até mesmo a diagnosticar as raízes concretas ("porquês") da alienação do trabalho, assim como vislumbra as possibilidades e caminhos ("como") para superar a realidade que subjuga o homem ao mundo inumano das coisas.
Os Manuscritos Econômico-Filosóf$\cos ^{3}$ fazem parte da crítica marxiana ao direito e ciência do Estado, que encontra seu auge teórico na filosofia hegeliana do Direito. Marx tinha a intenção de escrever vários volumes independentes desta crítica à ciência do Estado - Direito, Moral, Política, etc. -, sendo que os Manuscritos corresponderiam à crítica da economia política.

São apontamentos pessoais de estudo de Marx, que nunca foram redigidos para divulgação na forma que for - panfleto, livro, circular política, etc. Neles, o autor anota citações de livros e glosa-os em seguida, tece comentários e reflexões sobre diversos temas e esboça uma crítica da filosofia hegeliana nas suas páginas finais. Sem o devido cuidado da preparação final dos alfarrábios para publicação, páginas inteiras somem, idéias e argumentos são interrompidos no meio, e boa parte da obra não tem nexos de ligação entre os cadernos de estudo.

Estas são apenas uma das dificuldades para a compreensão destes manuscritos que Louis Althusser bem definiu como "enigmaticamente claros". Para completar este quadro aparentemente caótico, “(...) Marx, em seu esforço de entrar em diálogo com seus contemporâneos filosóficos, como Feuerbach, conservou certos termos do discurso deles que por vezes estavam em choque com o significado que ele próprio lhes atribuía" (MÉSZÁROS, 1981, p.15). Esta ambigüidade terminológica não se restringe ao linguajar próprio dos filósofos, pois Marx compila e reproduz inúmeras e extensas citações dos economistas, o que muitas vezes dificulta a diferenciação das idéias marxianas da dos autores citados.

Os Manuscritos de Paris representam, apesar das dificuldades inerentes à interpretação dos textos, um ponto de inflexão da maior importância na trajetória intelectual (e política) de Marx. Pela primeira vez, ele muda a perspectiva da alienação econômica fundada numa vaga antropologia idealista para um processo social enraizado na esfera da produção da vida humana. Enquanto Hegel naturaliza a objetivação do trabalho humano supondoa alienada em todos os modos de produção, como se o homem estivesse condenado a estar sempre separado do resultado do seu trabalho, 
Marx afirma que a objetivação alienada e a coisificação das relações de produção são resultados de uma forma histórica específica de organização social, a saber, a baseada na produção de mercadorias ${ }^{4}$.

$\mathrm{O}$ que era para ser apenas uma crítica ao sistema hegeliano acaba se tornando o segundo passo da crítica da economia política, dado que Engels já havia iniciado-a; o próprio Marx (1982 [1859], p.25) nos dá o seu testemunho sobre sua primeira incursão no terreno da Economia Política, quando percebe a sua importância crucial no entendimento da sociedade burguesa e na construção do socialismo científico.

Minha investigação desembocou no seguinte resultado: relações jurídicas, tais como formas de Estado, não podem ser compreendidas nem a partir de si mesmas, nem a partir do assim chamado desenvolvimento geral do espírito humano, mas, pelo contrário, elas se enraízam nas relações materiais de vida, cuja totalidade foi resumida por Hegel sob o nome de 'sociedade civil' (bürgerliche Gesellschaft) (...); mas que a anatomia da sociedade burguesa (bürgerliche Gesellschaft) deve ser procurada na Economia Política.

A base da sua crítica (filosófica) à economia política constitui-se na leitura de alguns poucos autores econômicos, do esboço da crítica da economia política de Friedrich Engels, e, mais importante, do contato com as condições de vida e a auto-organização política do proletariado parisiense. Neste momento da sua trajetória teórica, no auge da sua juventude, Marx ainda não tinha, inversamente do que afirma o autor logo no início dos Manuscritos $^{5}$ , um acúmulo suficiente e desejado de estudos sobre a economia política para dirigir-lhe um golpe fatal, como diria anos mais tarde na finalização das páginas de $O$ Capital (1867).

$\mathrm{O}$ que contrapor, então, à ideologia falseadora da economia burguesa? Qual é a saída para superar os limites da ideologia econômica? Partindo da sua experiência junto à militância política com o proletariado parisiense e do contato com a economia política apresentada por Engels, Marx elabora, nos Manuscritos, uma síntese em statu nascendi, um sistema coerente de idéias que interliga toda uma série de questões e temáticas, determinadas e determinantes do sistema que as acolhe. Segundo Izstán Mészáros (op. cit., p.17), estamos testemunhando neles o aparecimento dessa síntese singular, ao seguirmos as linhas gerais de uma vasta e abrangente concepção da experiência humana em todas as suas manifestações (...). Marx delineia nos Manuscritos de Paris as principais características de uma nova 'ciência humana' revolucionária (...) do ponto de vista de uma grande idéia sintetizadora: 'a alienação do trabalho' como a raiz de todo o complexo de alienações.

Os Manuscritos são, desta forma, uma peça teórica escrita por um jovem pensador marginalizado pelas escolas tradicionais, que se vê obrigado a desenvolver sua própria concepção de mundo ao largo das instituições acadêmicas. Eles são um balanço dos estudos marxianos realizados até então e um esboço não definitivo de uma agenda de pesquisa futura, que aponta para diversas áreas do saber, necessariamente articuladas numa nova concepção de mundo que as dê sentido e sustentação. "No curso da redação dos Manuscritos de Paris, Marx percebe a imensidão de seu empreendimento, ao adquirir consciência de que seu enfoque geral, orientado para a práxis, (...) deve proceder sempre 'por meio de uma análise totalmente empírica', submetendo ao mais rigoroso exame até mesmo os mínimos detalhes" (Ibid, p.21, grifo do autor). E assim será até os últimos dias da sua vida, buscando, incansavelmente, terminar uma obra interminável.

O objeto da sua crítica, a economia política, não foi uma escolha ao acaso, como uma área do saber passível de ser corrigida a partirdos seus próprios elementos constitutivos. Armado da crítica da filosofia do direito de Hegel, e inspirado pelos ensinamentos do genial esboço da crítica engelsiana, Marx enxerga a problemática da economia política como a chave do entendimento do homem e sua relação com a natureza e a sociedade. A economia política se torna sua fonte da preocupação quando Marx percebe-a como uma justificativa ideológica da alienação da sociedade capitalista, regida pela vontade de uma potência alheia aos desejos do trabalhador. Como diz Herbert Marcuse (1968 [1932], p.108),

esta economia política é a sanção científica da intervenção do mundo humano, histórico-social, num mundo estranho ao homem enquanto poder hostil do antagônico mundo da mercadoria e do dinheiro, no qual a maior parte da humanidade só existe ainda 
enquanto trabalhadores 'abstratos' (cindidos da completa realidade da existência humana), separada do objeto do seu trabalho, coagida a vender-se a si própria enquanto mercadoria, para poder manter apenas sua existência física em geral.

A tarefa posta por Marx diante de si na sua crítica da economia política não é trivial, nem de curta duração, pois ele não pretendia preencher as lacunas teóricas deixadas em aberto pelos economistas clássicos, muito menos identificar possíveis erros lógicos e formais na sua linguagem e na reprodução ideal da sociedade capitalista ${ }^{6}$. Marx não foi, nem pretendeu ser, o "último dos clássicos" ou um "ricardiano maior", como dizem marxólogos e comentadores da sua obra. O seu objetivo era fundamentar, através do reexame da filosofia clássica alemã e do ponto de vista do proletariado revolucionário, uma crítica positiva da economia política, capaz de elucidar os aspectos negativos da sociedade capitalista e apontar rumos de superação, transcendência (Aufhebung) desta forma de sociabilidade que subsume, formal e realmente, o homem ao mundo inumano das coisas. "Dentro desta crítica se transformará inteiramente a idéia de economia política: ela se modificará numa ciência das condições necessárias à revolução comunista" (Ibid, p.107).

O fato é que Marx havia despertado para a elaboração de uma síntese teórica superadora da filosofia clássica alemã, da economia política e do coletivismo francês (LÊNIN, 2003), síntese esta que nasce como expressão dos anseios e interesses do proletariado. Para alcançar este objetivo era preciso desvendar o código genético do capitalismo e sua estrutura molecular básica que Marx, primeiramente, identificou no trabalho e depois na mercadoria.

\subsection{Trabalho assalariado e propriedade privada: a alienação econômica}

O ponto de partida dos esquemas teóricos da economia política é, segundo as notas dos Manuscritos, a propriedade privada. Tomando-a como um dado natural e a-histórico, os economistas políticos não explicam a gênese da propriedade privada burguesa, quando e onde ela surgiu, nem quais são suas leis científicas internas, reduzindo-a a fórmulas abstratas e vazias de conteúdo sóciohistórico. Sem a preocupação de explicar e demonstrar cientificamente o processo histórico da formação da propriedade privada, os economistas políticos voltam todas as suas atenções para a análise antropológica da ganância e da dinâmica da concorrência.

$\mathrm{Na}$ antropologia smithiana, presente no livro A Riqueza das Nações, a produção de mercadorias é considerada adequada e satisfatória a "natureza humana", guiada pelo desejo de acumular riqueza e maximizar prazeres e minimizar a dor. Simbolizada na figura do Homo Economicus, a antropologia smithiana eterniza o desejo capitalista de acumulação de riquezas, estendendo-o aos períodos históricos precedentes, supondo que o homem sempre teve como princípio básico a ganância e o egoísmo burguês. "No mundo fictício dos economistas clássicos - mundo que não passa de uma extrapolação esquemática e idealista do mundo capitalista real - os homens seriam perfeitos, egoístas, indiferentes e insensíveis aos sofrimentos, aspirações e necessidades de seus semelhantes, mas que passariam (é nisso que consiste a idealização) seu tempo a ajudar os semelhantes, sem querer" (GOLDMANN, 1967, p.118).

Ao supor a propriedade privada como um fato dado e acabado, o economista político esquiva-se de explicar o processo histórico do surgimento da propriedade privada, de explicitar as suas especificidades e conseqüências sócio-econômicas no modo de produção capitalista e acaba por se refugiar num estado primitivo remoto e imaginário, numa espécie de ilha da fantasia - a ilha de Robinson Crusoé. Contrariamente ao procedimento adotado pelos economistas, Marx toma para si, nos seus apontamentos, o ponto de partida do real, da produção humana, da situação social dos trabalhadores. Segundo Mészáros (op. cit., pp.42-43),

\footnotetext{
A superioridade radical de Marx sobre todos os que o precederam é evidente na historicidade dialética coerente de sua teoria, em contraste com as debilidades de seus predecessores, que, em um momento ou outro, eram todos obrigados a abandonar o terreno real da história em favor de alguma solução imaginária das contradições que teriam percebido, mas não podiam dominar ideológica e intelectualmente.
}

O procedimento metodológico de reproduzir o real o mais fielmente possível, 
estabelecendo as conexões dinâmicas entre múltiplas determinações no âmbito da totalidade, diferencia e afasta Marx da economia política (LUKÁCS, 1979, capítulos 1 e 2). Mesmo ainda trabalhando com as categorias e linguagem próprias dos economistas, Marx estabelece os primeiros passos de ruptura ontológica e metodológica com a ciência econômica burguesa.

Os homens são analisados na sua vida concreta, na sua existência prática de transformação do mundo e de si mesmo, como produto e produtores da realidade social, diferentemente do Homo Economicus. Marx não adota o ponto de vista de um homem qualquer, abstrato, geral, mas o do trabalhador, o do proletariado, que corresponde à situação sócio-econômica de grande parte da humanidade ${ }^{7}$. Sua teoria começa a ganhar contornos de um recorte classista da realidade, embora o conceito de classes sociais não tenha surgido com coerência e precisão (CASTELO BRANCO, 2004).

Otrabalhoé, para Marx, uma categoria que ultrapassa suas significações econômicas: antes de tudo, ele significa a atividade vital da realização do homem como ser prático, como ser universal construtor da sua realidade social. Marx acusa a economia política de reduzir o trabalho ao emprego, e o trabalhador à condição de mão-de-obra, de instrumento de produção, de "uma besta reduzida às mais estritas necessidades corporais" (MARX, 2004 [1844], p.31), e vai propor uma nova concepção do homem, baseada numa nova concepção do trabalho.

O trabalho é a mediação primária do homem com a natureza, na sua apropriação dos bens naturais e transformação em produtos sociais. Os termos básicos da teoria da alienação de Marx podem ser assim definidos como Homem, Natureza e Trabalho. Não é possível pensarmos a relação do homem com a natureza sem falarmos no trabalho e nos objetos resultantes desta atividade do homem. Ele é uma mediação de primeira ordem na relação sujeito-objeto (homem-natureza), "um mediador que permite ao homem criar um modo humano de existência, assegurando que ele não recuará para o estado natural (...)" (MÉSZÁROS, op. cit., p.76).

O trabalho consciente diferencia o homem dos outros animais, pois estes carregam as suas formas de atuação na natureza no seu código genético. Já “o homem faz da sua atividade vital mesma um objeto da sua vontade e da sua consciência. Ele tem atividade vital consciente. Esta não é uma determinada (Bestimmtheit) com a qual ele coincide imediatamente. A atividade vital consciente distingue o homem imediatamente a atividade vital animal. Justamente, [e] só por isso, ele é um ser genérico" (Ibid, p.84).

A apropriação da natureza pelo homem não é feita apenas para a satisfação de necessidades biológicas imediatas. Isto diferencia os homens dos animais: enquanto estes "produzem" sob o ditame das necessidades e da herança genética natural, aqueles produzem não apenas para suprir carências, mas sim para realizar-se universalmente como ser genérico, como ser produtor da sua própria liberdade.

Numa primeira aproximação, o trabalho surge para o homem como uma atividade prática que lhe garante a sobrevivência física, explorando os recursos da natureza para sua alimentação, vestuário, habitação etc. Já em uma segunda abordagem, podemos dizer que o trabalho é também atividade prática consciente, teleológica, em que os projetos idealizados na mente humana se objetivam e se concretizam nos produtos do seu trabalho, onde os homens constroem a sua realidade social e a si mesmo num processo histórico contínuo e ininterrupto.

Ao produzir objetos através do seu trabalho, o homem se reconhece nos objetos produzidos por si e pelos outros membros da espécie, daí o gênero humano ser derivado do trabalho. O trabalho é, em suma, o processo social pelo qual o homem se auto-afirma e se auto-realiza, modificando a natureza e a si próprio na produção de objetos que lhes pertence. A posse completa e autêntica dos produtos do seu trabalho é parte integrante e fundamental da realização plena do homem enquanto trabalhador e ser genérico universal, pois o homem deve tanto se reconhecer na sua obra quanto dominá-la, tê-la de forma a exercer domínio completo sobre o resultado do seu trabalho.

Sob os ângulos da automediação necessária do homem com a natureza e, principalmente, do autodesenvolvimento humano, o trabalho é visto somente nos seus aspectos positivos, como manifestação de vida (Lebensäusserung). Mas o trabalho tem 
um lado obscuro, do qual Marx se encarregou de trazer à tona sob uma perspectiva diferente de Hegel, identificando as leis objetivas do mundo do trabalho e as forças sociais para superar o sentido negativo do trabalho, a alienação (Lebensentäusserung). Marx vai lutar contra o conformismo hegeliano de aceitar a objetivação humana alienada como um fato insuprimível do homem e exprimir, teoricamente, os meios e as forças sociais capazes de superá-la.

As categorias-chave para entender a alienação econômica são, dentro da teoria marxiana, atividades, divisão do trabalho, troca, propriedade privada e trabalho assalariado, todas elas analisadas, em maior ou menor grau, nos Manuscritos de Paris. Mas a categorização da alienação do trabalho só pode ser perfeitamente entendida se tivermos em mente o processo histórico do surgimento da propriedade privada capitalista e do trabalho assalariado, mediações de segunda ordem que surgem a partir da alienabilidade da terra e do homem e se interpõem entre o homem e a natureza.

O processo de alienação econômica tem um duplo caráter, que obedece a ditames sociais da ordem capitalista, como acabamos de falar. Primeiro, o trabalhador é alienado dos produtos do seu trabalho, que pertencem, privadamente, aos donos dos meios de produção. De sua posse, vende-os no mercado por um determinado valor de troca e retém os ganhos provenientes das vendas. Além da propriedade das mercadorias produzidas, os burgueses também controlam o processo de trabalho no qual o trabalhador está inserido, ganhando um salário em troca da sua humanidade perdida. O homem, assim, tornase uma mercadoria, e passa a (sub)existir enquanto sujeito físico, entidade meramente biológica, como os animais.

A alienação econômica, entretanto, não se esgota neste duplo caráter da alienação econômica - logo, não deve ser reconhecida como algo simples. Sua complexidade vai além e atinge outras esferas da vida do ser social. Em resumo, podemos descrevê-la da seguinte forma: 1. relação alienada do homem com a natureza, com os produtos da sua atividade; 2 . trabalhador alienado do processo de produção, uma atividade alheia a si; 3. o homem deixa de produzir-se como "ser universal" da natureza, como ser genérico, e passa a construir um ser individual que se auto-realiza na parcialidade limitada, e não mais na universalidade singular do homem (ou seja, o homem não se reconhece como membro de uma espécie); 4, alienação do homem com outros homens. E, por último, mas não menos importante, tem a transformação dos processos de alienação econômica em uma entidade externa ao homem, como se conjurada magicamente e que ganha vida própria, sem ninguém a controlála. É uma espécie de uma potência alheia aos desejos do homem, que Smith imortalizou sob o nome de mão invisível e Marx chamou de fetichismo da mercadoria.

\section{O fetichismo da mercadoria}

Dentro da totalidade da vida social, diversas totalidades parciais - economia, ciência, arte, direito, política, etc. - articulamse entre si de forma dialética, determinando e sendo determinadas numa relação de interação recíproca. Nenhum setor particular da vida social goza de uma preponderância natural sobre as outras, isto é, nenhuma totalidade parcial determina, de forma unívoca e absoluta, as outras partes constituintes do todo.

A economia emerge, segundo o materialismo histórico de Marx e Engels, como a base social fundante das relações humanas, pois “(...) os homens foram obrigados a dedicar a maior parte de sua atividade à resolução dos problemas referentes à produção e à distribuição das riquezas materiais (...)" (GOLDMANN, op. cit., p.110).

Esta afirmação de Goldmann (e Marx e Engels) nada mais é do que uma constatação empírica sobre a história dos homens elevada ao plano das idéias. Muito se falou e disse sobre um suposto caráter economicista da teoria de Marx e Engels por conta do primado dos fatores econômicos sobre outros momentos da realidade social. "Trata-se (...) apenas de uma primazia de fato, e não de direito, que desaparecerá naturalmente, no dia em que a aquisição de riquezas materiais passará-graças ao desenvolvimento das forças produtivas e a uma transformação da estrutura social - para segundo plano na atividade dos indivíduos. É o famoso 'salto' do reino da necessidade ao reino da liberdade" (Ibid, p.111).

Com o avanço do desenvolvimento capitalista, a esfera econômica ganha cada 
vez mais autonomia em relação aos demais momentos da totalidade, autonomia esta sempre relativa, pois não é verídico que a economia possa se separar por completo do todo, mas é verdade que expande sua lógica e seu domínio sobre as outras esferas sociais, seguindo de perto a mercantilização da vida humana dentro do capitalismo.

Nos modos de produção précapitalistas, como o escravagismo e o feudalismo, a divisão social do trabalho seguia um esquema rígido, onde as castas, estamentos e classes eram facilmente percebidas dentro da estratificação social. As unidades econômicas (tribos, famílias, clãs, cidades-Estado, etc.) eram limitadas tanto na produção dos bens quanto na troca externa. Nestes períodos históricos determinados, as unidades econômicas produziam para o seu próprio consumo e, um pequeno excedente, que por vezes aparecia como resíduo do processo de produção (nunca de forma voluntária), era utilizado na troca com outras unidades, ou seja, o intercâmbio entre unidades de produção era reduzido a poucos produtos e a poucas quantidades. A produção de bens não tinha como objetivo abastecer o mercado, nem gerar excedentes em larga escala, mas sim criar os meios de subsistência das unidades. A autarquia, enfim, era a regra geral. Tudo isto vai mudar radicalmente com o modo de produção capitalista.

Com o advento do capitalismo, a antiga divisão social do trabalho vai desaparecer e dar lugar a uma "anarquia da produção", forma menos rígida, nem por isto menos hierarquizada, de alocação e distribuição de recursos, e uma universalidade da economia, tanto geográfica quanto social.

O mercado é uma instituição social e econômica de alocação de recursos caracterizada pela ausência de um mecanismo centralizador e planificador da produção, distribuição, troca e consumo das mercadorias. No capitalismo, a concorrência adquire um papel central na anarquia da produção e acaba por exercer, por vias não-convencionais, o papel de uma instância permissivamente reguladora. "É por isso que esse mercado assume (...) o aspecto de uma realidade cega, objetiva e exterior (...)" (Ibid, p.113) até mesmo para os capitalistas, atingidos pelo processo de fetichismo. O mercado, criação humana, aliena-se e torna-se uma entidade onipotente e onisciente temida por seus adoradores, os burgueses. Ironia do destino ou fatalidade? Nenhum nem outro, responderia Marx: trata-se da evolução social do fetichismo da mercadoria, que a tudo e a todos abarca na esteira da acumulação ampliada e contínua do capital.

Ao contrário do ídolo, que se sustenta por si próprio, o fetiche é um objeto que necessita ser carregado no corpo de alguém, ou de alguma coisa. No capitalismo ele é carregado pela mercadoria, célula fundamental para a análise do DNA do capitalismo, tarefa a qual Marx vai mergulhar nos Grundisse e em O Capital.

A publicação dos Grundisse, mesmo que tardia, provou que Marx nunca abandonou sua teoria da alienação, mas a saturou de novas determinações formais ${ }^{8}$ com a teoria do valortrabalho, desenvolvida cuidadosamente desde a Miséria da Filosofia, onde o revolucionário alemão ainda caminhava com as pernas ricardianas, ou melhor, com a teoria do valortrabalho de David Ricardo. A temática do fetichismo aparece (sub)desenvolvida nos Grundisse 9 , ponto central da investigação marxista sobre a sociedade burguesa mercantil. Anos mais tarde, quando redige $O$ Capital, exposição final da crítica da economia política, "o seu discurso teórico alcança aí um rigor inaudito, subordinado diretamente à fidelidade ao objeto, reposto, pela abstração, totalizadoramente, na mais rica multiplicidade de conexões, superandose a sua imediaticidade empírica na sua reprodução concreta" (NETTO, 1981, p.38).

Em O Capital, Marx descreve a mercadoria como uma espécie de artefato capaz de ocultar as relações humanas envolvidas na produção do objeto. Antes da análise marxiana sobre o capital, o capitalismo era descrito pelos economistas vulgares como um imenso sistema de circulação e troca de bens. O processo de trabalho humano, que confere vida, valor e conteúdo ao capitalismo, desaparece nas brumas ideológicas da economia vulgar, como um feitiço, como um passe de mágica. Coube a Marx desvendar o fetichismo da mercadoria e seu caráter desumano, coisificado como decorrente de relações sociais de produção, e não de uma característica intrínseca aos objetos.

O fetichismo da mercadoria, que pressupõe uma teoria da alienação, é, na 
verdade, uma manifestação da alienação econômica numa determinada sociedade histórica, a capitalista. Podemos dizer, assim, que, enquanto a alienação é um processo que perpassa diversos modos de produção, e diversas modalidades - religiosa e política -, o fetichismo da mercadoria é uma particularidade econômica do modo de produção capitalista.

A tradição marxista, a partir de algumas interpretações particulares da crítica da economia política, isolou a teoria do fetichismo da mercadoria do todo marxiano, e tomou-a ora como um apêndice sociológico, ora como uma crítica cultural. Isaak Rubin, nos anos 1920, interpretou de forma inovadora o famoso capítulo 1 do livro I de $O$ Capital, tido como muitos como algo incompreensível, ou descolado do debate que Marx empreendia com a economia política. Segundo o economista russo, a teoria do fetichismo da mercadoria é "a base de todo o sistema econômico de Marx, particularmente de sua teoria do valor" (RUBIN, 1980, p.19).

Diz o ditado popular que as aparências enganam. O método da economia política, curiosamente, atém-se justamente a aparência das relações econômicas, e delas não saem. Seu horizonte analítico e teórico é o mundo das trocas mercantis. Marx vai de encontro a ambas as formas de consciência, a popular e a científica da economia política. Ao contrário dos economistas políticos clássicos, que viam as relações econômicas como relações entre coisas, e dos economistas vulgares, que viam as mesmas transações como relações entre pessoas e coisas, (Ibid, p.15), Marx supera o senso comum popular e o método da economia política, restrito às aparências dos fenômenos sociais, e acaba com certas ilusões próprias do capitalismo, desvendando o mistério de como as relações sociais de produção entre sujeitos históricos aparecem como relações entre coisas. Segundo o pensador alemão (2003 [1867]: 94),

O caráter misterioso que o produto do trabalho apresenta ao assumir a forma de mercadorias, donde provém? Dessa própria forma, claro. A igualdade dos trabalhos humanos fica disfarçada sob a forma da igualdade dos produtos do trabalho como valores; a medida, por meio da duração, do dispêndio da força humana de trabalho, toma a forma de quantidade de valor dos produtos do trabalho; finalmente, as relações entre os produtores, nas quais se afirma o caráter social dos seus trabalhos, assumem a forma de relação social entre os produtos do trabalho.
No primeiro capítulo de $O$ Capital, Marx "indaga-se porque a produção mercantil dominante, instaurando-se sobre fundamentos puramente sociais, obscurece e escamoteia estes mesmos fundamentos" (NETTO, op. cit., p.40). O processo social do trabalho, na sociedade mercantil capitalista, acaba por mascarar o seu caráter social e se mostrar como atividades de homens atomizados em unidades de produção isoladas uma das outras.

As relações sociais de produção entre os trabalhadores livres desaparecem sob o manto das trocas mercantis do capitalismo que, contraditoriamente, é o modo de produção mais desenvolvido do ponto de vista da divisão técnica e social do trabalho. Os produtos do trabalho humano não são reconhecidos como resultado da cooperação entre diversos trabalhadores e ramos da indústria - “(...) nada disso é visível; a maioria desses personagens não se conhece e até ignoram sua existência mutuamente. Ficariam todos espantados de saber da existência de um laço que os une" (GOLDMANN, op. cit., p.122).

O reconhecimento dos laços qualitativos de solidariedade e da união operária fica subsumido ao reconhecimento do caráter social das trocas mercantis, estas sim provedoras da argamassa que aparentemente solidifica a sociedade capitalista, que tem como sua maior expressão o equivalente geral - o dinheiro. É somente no âmbito da circulação que os homens se encontram e se reconhecem como iguais, comercializando valores de troca quantificados no preço, mecanismo social que permite o intercâmbio das mercadorias por diversos agentes.

Aresposta do segredo do fetichismo da mercadoria - da reificação das relações sociais de produção - não está na propriedade material das coisas produzidas pelo trabalhador ${ }^{10}$, nem somente nas relações de troca entre agentes econômicos independentes e que produzem atomizadamente. Ela reside, antes de tudo, na estrutura social da economia capitalista, constituída historicamente de forma muito particular. Uma das principais conquistas de Marx no exame sobre trabalho, mercadoria e valor é tomar a produção mercantil como um processo histórico em movimento. Indo além da positividade imediata da realidade, que manifesta as relações sociais de sujeitos como relações entre coisas, ele foi capaz de desvendar o caráter histórico da produção 
mercantil, dando um passo decisivo na crítica da economia política, já que a tendência dos economistas clássicos, vulgares ou não, era a de naturalizar as categorias de análise e eternizar o modo de produção capitalista.

Mas isso não esgota a teoria do fetichismo da mercadoria, conforme nos chama a atenção Rubin: "Marx não mostrou apenas que as relações humanas eram encobertas por relações entre coisas, mas também que, na economia mercantil, as relações sociais de produção assumem inevitavelmente a forma de coisas e não podem se expressar senão através de coisas" (RUBIN, op. cit., pp.19-20). Ou, nas palavras do próprio Marx (2003 [1867], p.94): "chamo a isto de fetichismo, que está sempre grudado aos produtos do trabalho, quando são gerados como mercadorias. É inseparável da produção de mercadorias". Em poucas palavras, para resumirmos o argumento, o fetichismo da mercadoria não é tido por Marx como uma ilusão criada na consciência (distorcida) dos agentes econômicos, ou mesmo dos sicofantas da burguesia, mas é a forma social inevitável e necessária pela qual as relações sociais de produção capitalista se materializam, ganhando, desta maneira, uma base objetiva ${ }^{11}$.

\section{A superação positiva da alienação na crítica da economia política}

Tomando a realidade burguesa como um dado natural, sem contestar os seus fundamentos, sem vasculhar seus recônditos mais secretos, as suas raízes mais profundas, os economistas políticos tornam a ciência econômica como uma ciência do capitalismo. Ao não investigar a gênese histórica das suas categorias fundantes - trabalho e propriedade privada, dentre outras - a economia política clássica naturaliza as relações sociais de produção subjacentes ao plano da aparência econômica (troca, consumo e distribuição), eterniza suas categorias analíticas que reproduzem a positividade capitalista e, com isto, acaba por legitimar o mundo desumano do trabalho alienado e ofuscar rotas alternativas de construção de uma nova ordem social.

A economia política clássica expressa relações sociais de um mundo alienado, em que o produtor direto produz a riqueza social privadamente apropriada pelas classes dominantes e, ao mesmo tempo, se empobrece, absoluta e/ou relativamente, quanto mais riqueza produz. O trabalho assalariado, ao invés de criar possibilidades de realização das infinitas potencialidades humanas, acaba por forjar grilhões de miséria e degradação dos trabalhadores.

Com a formulação da categoria fetichismo da mercadoria, Marx determina a raiz sócio-econômica da generalidade da alienação contida nos Manuscritos de Paris. Inter-relacionando alienação, valor, trabalho e propriedade, o nosso autor transcende a crítica filosófica da economia política, elevando-a a um novo patamar, na qual a economia política ganha uma nova perspectiva de mundo - o materialismo histórico -, um novo método - a dialética - e um objeto desnaturalizado, histórica e socialmente determinado - o modo de produção capitalista. A crítica marxiana da economia política pressupõe um rico arcabouço filosófico de categorias hegelianas previamente reformuladas, no qual o tema alienação exerce papel de destaque, o de desvendar os processos do capitalismo que coisificam as relações sociais entre os produtores.

A crítica da economia política, extenso projeto de pesquisa que ocupou mais de vinte anos da vida de Karl Marx, não significa repúdio, mas um profundo mergulho naquela ciência que traz a chave da anatomia da sociedade burguesa (NICOLAUS, 2003, p.106). Mas não somente isso: ela, a crítica, é positiva, ou seja, traz em si negação e superação, a proposta de algo novo que nasce do velho, uma nova organização societal de libertação do homem dos grilhões do capital. Ernest Mandel (2001 [1970], p.36) insiste no ponto que "a teoria marxista a alienação é (...) incompleta enquanto não for capaz de formular uma teoria de desalienação progressiva e não se defender com êxito contra o mito da 'alienação inevitável' em toda e qualquer 'sociedade industrial'",

Sendo uma categoria historicamente verificável, a alienação é uma realidade social produto de complexas interações entre diversos sujeitos e classes sociais e, por isto, suscetível a mudanças, com possíveis avanços, regressões e até mesmo o seu desaparecimento completo, de acordo com certas premissas históricas. Era nisto que Marx acreditava quando escreveu, em diversos livros, inclusive em $O$ Capital, sobre 
a sociedade comunista - o reino da liberdade - onde desapareceriam a propriedade privada, a divisão social do trabalho, o dinheiro, o Estado e as classes. Os produtores diretos se livrariam, assim, da "maldição eterna" do trabalho alienado, se tornando livres e capazes tanto de suprirem suas necessidades materiais quanto desenvolverem ao máximo suas capacidades individuais e o gênero humano universal.

\section{Referências}

- CASTELO BRANCO, Rodrigo. Capitalismo e classes sociais: notas críticas sobre o percurso teórico de Karl Marx. In: Oikos, número 3. Rio de Janeiro: Instituto de Economia/UFRJ, 2004.

- GOLDMANN, Lucien. A reificação. In: Dialética e cultura. Lucien Goldmann. Rio de Janeiro: Paz e Terra, 1967.

- HYPPOLITE, Jean. Lukács y el joven Hegel. In: Lukács. Diversos autores. Buenos Aires: Editorial Jorge Alvarez, 1969.

- LENIN, V.I. As três fontes do marxismo. $2^{\mathrm{a}}$ edição. São Paulo: Expressão Popular, 2003.

\section{- LUKÁCS, Georg. Ontologia do ser social:} os princípios ontológicos fundamentais de Marx. São Paulo: Ciências Humanas, 1979.

- MANDEL, Ernest e NOVACK, George. The marxist theory of alienation. 8th edition. New York: Pathfinder, 2001 [1970].

- MARCUSE, Herbert. Novas fontes para a fundamentação do materialismo histórico (interpretação dos recém-publicados manuscritos de Marx). In: Materialismo histórico e existência. Herbert Marcuse. Rio de Janeiro: Tempo Brasileiro, 1968 [1932].

- MARX, Karl. Manuscritos EconômicoFilosóficos. São Paulo: Boitempo, 2004 [1844]

Prefácio a Para a Crítica da Economia Política. In: Para a Crítica da Economia Política; Salário, preço e lucro; o rendimento e suas fontes: a economia vulgar. Karl Marx.
São Paulo: Abril Cultural, 1982 [1857].

Elementos fundamentales para la crítica de la economia política (borrador) 1857-1858. Volúmenes 1 e $2.4^{\mathrm{a}}$ edición. Buenos Aires: Siglo XXI, 1974 [1857-58].

- _ _ O Capital: crítica da economia política. Livro I, volume 1: o processo de produção do capital. $21^{\mathrm{a}}$ edição. Rio de Janeiro: Civilização Brasileira, 2003 [1867].

- MÉSZÁROS, István. Marx: a teoria da alienação. Rio de Janeiro: Zahar, 1981 [1970].

- NETTO, José Paulo. Capitalismo e reificação. São Paulo: Ciências Humanas, 1981

- NICOLAUS, Martin. Marx e o desconhecido. In: Marx e o socialismo. César Benjamin (org.) São Paulo: Expressão Popular, 2003.

- RUBIN, Isaak Illich. A teoria marxista do valor. São Paulo: Brasiliense, 1980.

-SCHAFF, Adam. Marxismo e existencialismo. Rio de Janeiro: Zahar, 1965.

\footnotetext{
${ }^{1}$ Aqui nos referimos aos livros Manuscritos EconômicoFilosóficos, A Ideologia Alemã (escrito em parceria com Friedrich Engels) e os Grundrisse.

${ }^{2} \mathrm{O}$ principal motivo tem fundamentos políticos e deve ser buscado no período de desestalinização que o marxismo começou a viver nos anos 1950. Após as denúncias dos crimes em massa cometidos durante a Era Stálin, diversos pensadores marxistas buscaram uma fonte de inspiração no jovem Marx para criar alternativas humanistas e democráticas ao stalinismo, um regime político que seria uma "aberração" segundo os ideais libertários dos primeiros escritos marxianos.
}

3 Os Manuscritos Econômico-Filosóficos também são conhecidos como Manuscritos de Paris ou Manuscritos de 1844. Ao longo do texto o leitor encontrará todas estas formas de nomenclatura aos Manuscritos.

4 Apesar das suas tendências existencialistas, Jean Hyppolite afirma, acertadamente, que o debate central de Marx com Hegel sobre alienação está na crítica marxiana à confusão que Hegel faz entre objetivação e alienação (HYPPOLITE, 1969, pp.102-3). Marx, nos Manuscritos, diferencia objetivação de exteriorização, 
5 “Ao leitor familiarizado com a economia nacional não preciso assegurar que meus trabalhos foram obtidos mediante uma análise inteiramente empírica, fundada num meticuloso estudo crítico da economia nacional" (MARX, 2004 [1844], p.19-20)

${ }^{6}$ Marx não se furtou a fazer este trabalho hercúleo de glosar as principais obras da economia política. Durante dez anos, ele freqüentou o Museu Britânico, pesquisou e comentou nada menos do que todos os principais tratados de economia política da sua época, apontamentos estes reunidos no quarto volume de $O$ Capital, editados postumamente por Karl Kautsky, que intitulou estas notas de estudo da história do pensamento econômico de Teorias da mais-valia.

7 A concepção marxiana do homem, presente nos Manuscritos de Paris, é pautada, principalmente, pelo debate com Ludwig Feuerbach, filósofo alemão que gozava de alto prestígio entre os hegelianos de esquerda e Marx, que o vê “(...) como o único que tem para com a dialética hegeliana um comportamento sério, crítico, e [o único] que fez verdadeiras descobertas nesse domínio" (MARX, 2004 [1844], p.117). Ela surge como uma dupla oposição: oposição tanto ao Homo Economicus quanto à antropologia de Feuerbach.

${ }^{8}$ Sobre a importância da categoria "determinação formal" na crítica da economia política, Cf. Rubin (1980), pp.5052.

9 Nos Grundrisse, Marx ainda não desenvolveu na plenitude a sua teoria do fetichismo, no sentido de saturar a teoria da alienação com novas determinações econômicas. Vale notar que nosso autor só menciona em uma única passagem o conceito de fetichismo, enquanto o conceito de alienação aparece recorrentemente ao longo dos rascunhos de estudo.

10 “(...) a forma mercadoria e a relação de valor entre os produtos do trabalho, a qual caracteriza essa forma, nada têm a ver com a natureza física desses produtos (...)" (MARX, 2003 [1867], p.94)

11 "As relações sociais de produção assumem, inevitavelmente, uma forma reificada e, na medida em que falamos das relações entre produtores mercantis individuais e não de relações dentro de firmas privadas isoladas, elas só existem e se realizam dessa forma”; “(...) o movimento dos preços das coisas no mercado não é apenas o reflexo das relações de produção entre as pessoas: é a única forma
(...) a coisa não só oculta as relações de produção entre as pessoas, como também as organiza, servindo como elo de ligação entre as pessoas. "Mais exatamente, oculta as relações de produção precisamente porque as relações de produção só se realizam sob a forma de relações entre as coisas" (RUBIN, op. cit., pp.24-25).

\section{Informação bibliográficas:}

Conforme a NBR 6023:2002 da Associação Brasileira de Normas Técnicas (ABNT), este texto científico publicado em periódico eletrônico deve ser citado da seguinte forma:

CASTELO BRANCO, R.. Maldições, Fetiches e Comunismo na Crítica da Economia Política: a teoria da alienação de Karl Marx. Cadernos UniFOA, Volta Redonda, ano III, n. 6, abril. 2008. Disponível em: $<$ http://www.unifoa.edu.br/pesquisa/caderno/edicao/06/28.pdf $>$ 